\title{
Electrochemical Impedance Spectroscopy Study on Anodic Dissolution of Fe-Ni Alloy in Sulfuric Acid Solution
}

\author{
Masayuki ITAGAKI, ${ }^{*}$ Naotake HASEBE, and Kunihiro WATANABE
}

\begin{abstract}
Science University of Tokyo, Department of Industrial Chemistry, Faculty of Science and Technology (Noda-shi, Chiba 278-8510, Japan)
\end{abstract}

\author{
Received March 10, 1999 ; Accepted July 15, 1999
}

\begin{abstract}
The anodic dissolution mechanism of Fe-Ni alloy was investigated by an electrochemical impedance spectroscopy (EIS). The Fe(II) and Ni(II) dissolved from Fe-Ni alloy electrode were detected simultaneously during the polarization curve measurement by a channel flow electrode system. The preferential dissolution of Fe(II) was observed at low anodic potentials, and the dissolution rate of Fe(II) was controlled by Ni content significantly. Nyquist plot of electrochemical impedance of $\mathrm{Fe}-\mathrm{Ni}$ alloy electrode shows an inductive semicircle and negative resistance. These unique loci were explained by the formation of adsorbed intermediates $\mathrm{Fe}(\mathrm{I})_{\mathrm{ad}}$ and $\mathrm{Ni}(\mathrm{I})_{\mathrm{ad}}$. The numerical simulation was performed for the experimental results of polarization curves, dissolution currents of $\mathrm{Fe}(\mathrm{II})$ and $\mathrm{Ni}$ (II) and electrochemical impedance responses. The dissolution mechanism was discussed on the basis of the kinetic parameters obtained by the simulation.
\end{abstract}

Key Words : Electrochemical Impedance Spectroscopy, Anodic Dissolution, Fe-Ni Alloy, Channel Flow Electrode

\section{Introduction}

$\mathrm{Ni}$ is one of the major elements in stainless steel, and the studies on its corrosion resistance are very significant. Therefore, many researchers have investigated the role of $\mathrm{Ni}$ for improvement of corrosion resistance of stainless steel using its binary alloys. The most of the reports concerning electrochemical behavior of $\mathrm{Fe}-\mathrm{Ni}$ alloys are about the component and structure of the passive film. Nagasaki et al. ${ }^{1)}$ investigated the nature of the passive film on $\mathrm{Fe}-\mathrm{Ni}$ alloys by X-ray microanalysis and X-ray diffraction, and discussed the relation between passive film and sulfate ions. Okuyama and Haruyama ${ }^{2)}$ estimated the thickness and chemical composition of the passive film on Fe-Ni alloys in borate solution by coulometry, and examined the influence of alloy composition, electrode potential and $\mathrm{pH}$ of the solution on the passive film nature. Morioka and Sakiyama ${ }^{3}$ investigated the influence of $\mathrm{Ni}$ component in $\mathrm{Fe}-\mathrm{Ni}$ alloys on the anodic current and the passivation potential in sulfuric acid solution. Ponthiaux et al ${ }^{4)}$ measured the polarization curve of the $\mathrm{Fe}-31 \% \mathrm{Ni}$ alloy in sulfuric acid solution by a rotating disk electrode. Okuyama ${ }^{5}$ applied a rotating ring disk electrode to the investigation of anodic dissolution of $\mathrm{Fe}-\mathrm{Ni}$ alloy in sulfuric acid solution, and reported the preferential dissolution of $\mathrm{Fe}(\mathrm{II})$ from $\mathrm{Fe}-\mathrm{Ni}$ alloy electrode. However, important subjects have remained on the anodic dissolution of $\mathrm{Fe}-\mathrm{Ni}$ alloy, i.e., information regarding adsorbed intermediate and kinetic analysis of the detailed dissolution mechanism.

Keddam et $a l .{ }^{6)}$ studied the effect of $\mathrm{Cr}$ component on the dissolution rate of $\mathrm{Fe}$ from a $\mathrm{Fe}-\mathrm{Cr}$ alloy by measuring polarization curves and electrochemical impedance spectroscopy (EIS), and proposed the dissolution mechanism of $\mathrm{Fe}-\mathrm{Cr}$ alloy on the basis of experiment results. They ${ }^{6}$ reported that the anodic dissolution potential and the passivation potential of $\mathrm{Fe}-\mathrm{Cr}$ alloys shifted toward negative potential with increasing the $\mathrm{Cr}$ component, and obtained the kinetic parameters of the elementary reactions of anodic dissolution of the Fe-Cr alloy by the numerical simulation on the experimental results. Anngergren et al..$^{7}$ got the information about an intermediate in $\mathrm{Fe}-\mathrm{Cr}$ dissolution by the measurement of electrochemical impedance and the dissolution efficiency of $\mathrm{Fe}$ (II) in the frequency domain.

In the present study, channel flow electrode method is applied to the investigation of $\mathrm{Fe}-\mathrm{Ni}$ alloy dissolution because the each dissolved ion can be detected independently during the measurement of polarization curve. Furthermore, EIS is applied to it in order to obtain the kinetic parameters of the detailed dissolution process of $\mathrm{Fe}-\mathrm{Ni}$ alloy and the information concerning the adsorbed intermediate.

\section{Experimental Method}

The scheme of a channel flow electrode is shown in Fig. 1. Figure 1(a) depicts the zoom up of the double electrode system, ${ }^{8)}$ and it was used when one kind of ions which dissolved from pure $\mathrm{Ni}$ and $\mathrm{Fe}$ were detected. The collecting electrode was separated at right angle to the electrolyte flow direction in Fig. 1 (b), and the separation-type collecting electrode system ${ }^{9)}$ was used for simultaneous detection of both $\mathrm{Fe}$ (II) and $\mathrm{Ni}(\mathrm{II})$ which dissolved from $\mathrm{Fe}-\mathrm{Ni}$ alloy. Pure $\mathrm{Fe}$ 


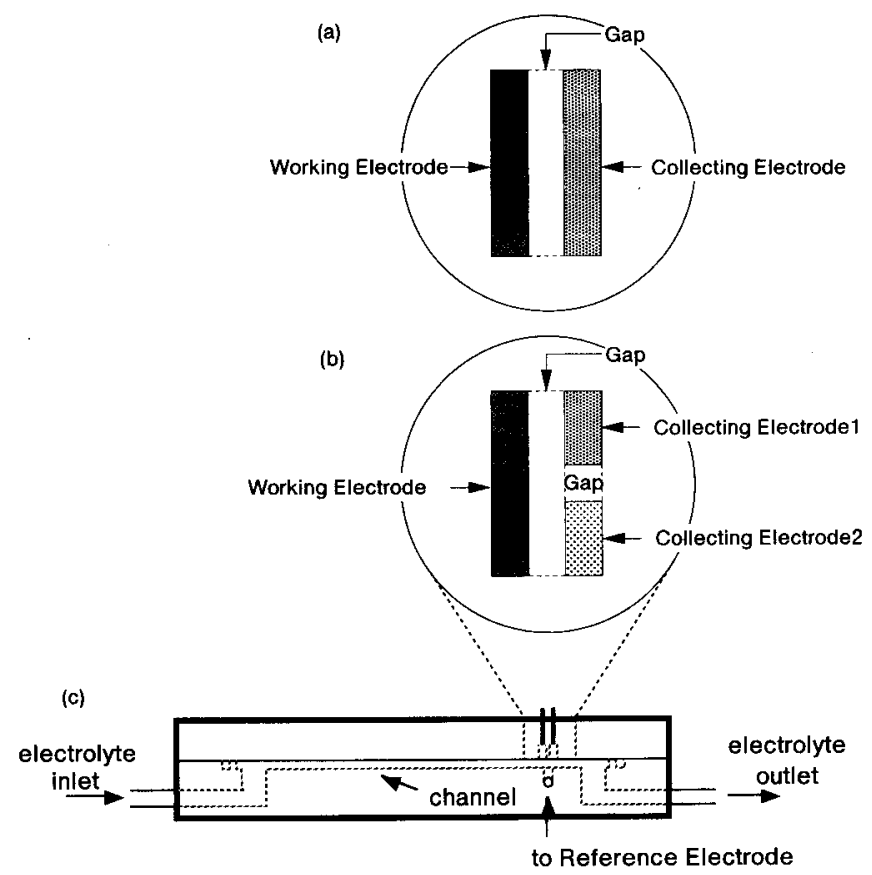

Fig. 1 (a) Zoom up of channel flow double electrode in contact with the electrolyte solution. (b) Zoom up of the separation-type channel flow electrode. (c) Scheme of channel flow cell.

(99.99\%, Johnson matthey), pure Ni (99.99\%, Nilaco) and $\mathrm{Fe}-x \mathrm{wt} \% \mathrm{Ni}(x=20,40,60,80)$ alloys were used for the working electrode. Fe- $x$ wt $\%$ Ni $(x=20,40,60,80)$ alloys were made from $99.9 \% \mathrm{Ni}$ and $99.99 \% \mathrm{Fe}$ by the argon arc melting method. The heat-treatment condition for the working electrode materials is as follows. A furnace was cooled to the room temperature after the specimen was heated to $900{ }^{\circ} \mathrm{C}$ at a speed of $250{ }^{\circ} \mathrm{C} / \mathrm{hr}$ in hydrogen gas stream and maintained for $10 \mathrm{hr}$ at $900{ }^{\circ} \mathrm{C}$. Glassy carbon and $\mathrm{Pb}$ $(99.99 \%$, Nilaco) were used for the collecting electrodes to detect $\mathrm{Fe}(\mathrm{II})$ and $\mathrm{Ni}(\mathrm{II})$, respectively. The collecting electrodes were arranged at the downstream of the working electrode with a gap of 0.05 $\mathrm{mm}$. The dimension of the working and collecting electrodes in double electrode system in Fig. 1 (a) were $4 \mathrm{~mm}$ wide and $1 \mathrm{~mm}$ long to the flow direction. In the case of separation-type collecting electrode system, the dimension of two collecting electrodes was $2 \mathrm{~mm}$ wide and $1 \mathrm{~mm}$ long, and their gap held a distance of $0.05 \mathrm{~mm}$. A saturated $\mathrm{KCl}-\mathrm{AgCl} / \mathrm{Ag}$ electrode (SSE) and platinum were used for reference and counter electrodes, respectively. The electrode potential in the present paper is represented by the SSE standard. The working electrode was rinsed by methanol and double distilled water successively after polishing by an emery paper of \#2000. The electrolyte solution was a mixture of $0.5 \mathrm{kmol} / \mathrm{m}^{3} \mathrm{H}_{2} \mathrm{SO}_{4}$ and $0.5 \mathrm{kmol} / \mathrm{m}^{3} \mathrm{Na}_{2} \mathrm{SO}_{4}$, and was adjusted to $\mathrm{pH} 1$. The electrolyte solution used in these experiments was prepared from the double distilled water and the analytical grade chemical reagent, and was deaerated by passing nitrogen gas for $24 \mathrm{hr}$ before measurement.

In the measurement of polarization curve, the work- ing electrode potential was scanned at $100 \mathrm{mV} / \mathrm{min}$ toward noble potential, and the working and collecting electrode currents were recorded. $\mathrm{Fe}(\mathrm{II})$ and $\mathrm{Ni}(\mathrm{II})$, which were dissolved from the working electrode, were detected on the collecting electrode at $1.4 \mathrm{~V}$ and $-1.2 \mathrm{~V}$, respectively.

The electrochemical impedance $Z(\omega)$ was measured by using frequency response analyzer (FRA). The amplitude of alternative voltage on the working electrode was $10 \mathrm{mV}$ (rms), and frequency range used for the measurement was from $10 \mathrm{mHz}$ to $10 \mathrm{kHz}$. The measurement was started at $20 \mathrm{~min}$ after the polarization at arbitrary potential. The mean flow rate of the electrolyte solution was $2 \mathrm{~m} / \mathrm{s}$ in all the experiments.

\section{1 Polarization curves}

\section{Experimental Results}

Figure 2 shows the polarization curves of Fe (a) and $\mathrm{Ni}(\mathrm{b})$ in sulfuric acid solution of $\mathrm{pH} 1$. The polarization curve of $\mathrm{Fe}$ shows a cathodic current region below an immersion potential of $-0.49 \mathrm{~V}$, and an anodic current region above $-0.49 \mathrm{~V}$. The cathodic current is related to the hydrogen evolution reaction. On the other hand, the polarization curve of Ni shows that the immersion potential (zero current potential) is approximately $-0.12 \mathrm{~V}$, indicating that $\mathrm{Fe}$ dissolves at more negative potential than $\mathrm{Ni}$. The dissolution currents of $\mathrm{Fe}(\mathrm{II}), i_{\mathrm{Fe}(\mathrm{II})}$, and $\mathrm{Ni}(\mathrm{II}), i_{\mathrm{Ni}(\mathrm{II})}$, were determined from the collecting electrode current $i_{\mathrm{c}}$ according to the following expressions.
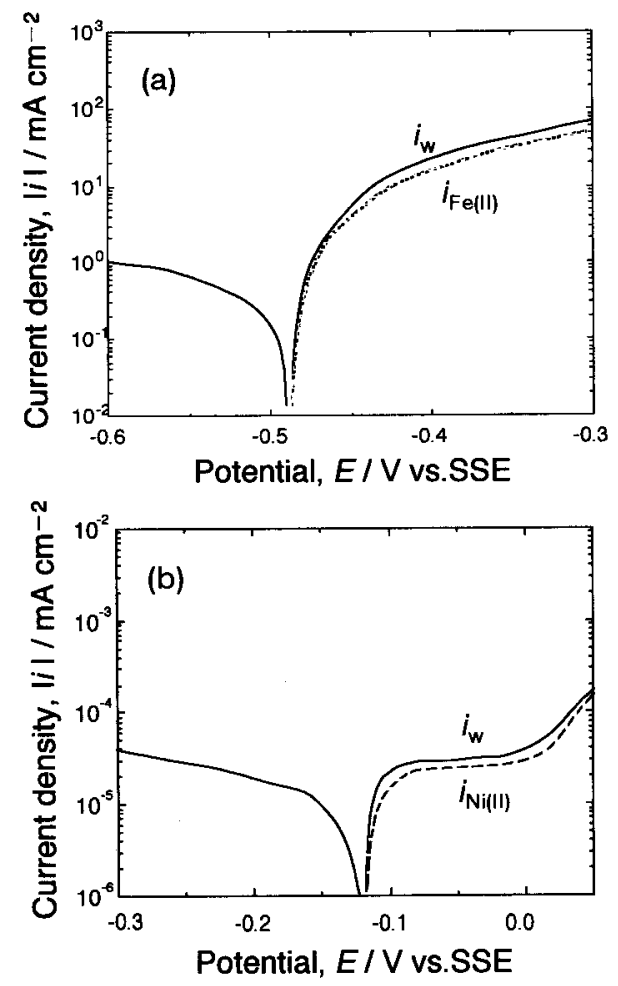

Fig. 2 (a) Polarization curve of $\mathrm{Fe}$ and $\mathrm{Fe}(\mathrm{II})$ dissolution current and (b) polarization curve of $\mathrm{Ni}$ and $\mathrm{Ni}$ (II) dissolution current in sulfuric solution $(\mathrm{pH} \mathrm{1})$. The solid and dotted lines denote the working electrode currents and dissolution currents, respectively. 


$$
\begin{aligned}
& i_{\mathrm{Fe}(\mathrm{II})}=2 i_{\mathrm{c}} / N_{\mathrm{s}} \\
& i_{\mathrm{Ni}(\mathrm{II})}=-i_{\mathrm{c}} / N_{\mathrm{s}}
\end{aligned}
$$

The collection efficiencies $N_{\mathrm{s}}$ for $\mathrm{Fe}$ (II) and $\mathrm{Ni}$ (II) in the double electrode system were measured to be 0.39 and 0.35 , respectively. The anodic currents of both $\mathrm{Fe}$ and $\mathrm{Ni}$ are coincided with $i_{\mathrm{Fe}(\mathrm{II})}$ and $i_{\mathrm{N}(\mathrm{II})}$, respectively.

Figure 3 shows polarization curves of the $\mathrm{Fe}-\mathrm{Ni}$ alloys and $i_{\mathrm{Fe}(\mathrm{II})}$ and $i_{\mathrm{Ni}(\mathrm{II})}$ in the sulfuric acid solution of pH 1. $N_{\mathrm{s}}$ 's of separation-type collecting system are 0.19 and 0.17 for $\mathrm{Fe}(\mathrm{II})$ and $\mathrm{Ni}(\mathrm{II})$, respectively. The preferential dissolution of $\mathrm{Fe}$ (II) from $\mathrm{Fe}-\mathrm{Ni}$ alloy is observed in small anodic polarizations, and this result is in good agreement with the report by Okuyama. ${ }^{57}$ This phenomenon is more significant when the $\mathrm{Ni}$ component in $\mathrm{Fe}-\mathrm{Ni}$ alloy is smaller. The start potentials of $\mathrm{Fe}(\mathrm{II})$ and $\mathrm{Ni}$ (II) dissolutions shift toward noble with increasing the amount of $\mathrm{Ni}$ component. $\mathrm{Fe}(\mathrm{II})$ preferential dissolution rate decreased greatly with increasing the $\mathrm{Ni}$ content, and however this result cannot be explained only by the decrease of $\mathrm{Fe}$ content. The start potential for $\mathrm{Ni}$ (II) dissolution becomes noble when the $\mathrm{Ni}$ content is larger.

\section{2 Electrochemical impedance response}

The Nyquist plots of electrochemical impedance responses $Z(\omega)$ of $\mathrm{Fe}-x$ wt $\% \mathrm{Ni}(x=20,40,60,80)$ in the sulfuric acid solution (pH1) are shown in Figs. 4-7. In Fig. 4, capacitive and inductive semicircles are observed on $Z(\omega)$ of $\mathrm{Fe}-20 \mathrm{wt} \% \mathrm{Ni}$ alloy below -0.3 $\mathrm{V}$, and the shape is similar to that of $\mathrm{Fe}^{.{ }^{10)}}$ It was shown that the preferential dissolution of Fe(II) occured below $-0.3 \mathrm{~V}$ in Fig. 3. From these results, the $\mathrm{Fe}(\mathrm{II})$ dissolved by a consecutive dissolution mechanism and the inductive semicircle originated from the adsorbed intermediate of $\mathrm{Fe}^{11)}$ in this potential region. On the other hand, when potential is at $-0.25 \mathrm{~V}$ and $-0.2 \mathrm{~V}$, the second capacitive semicircle appears on $Z(\omega)$. Because the dissolution of $\mathrm{Ni}(\mathrm{II})$ begins at $-0.3 \mathrm{~V}$ in Fig. 3, the second capacitive semicircle

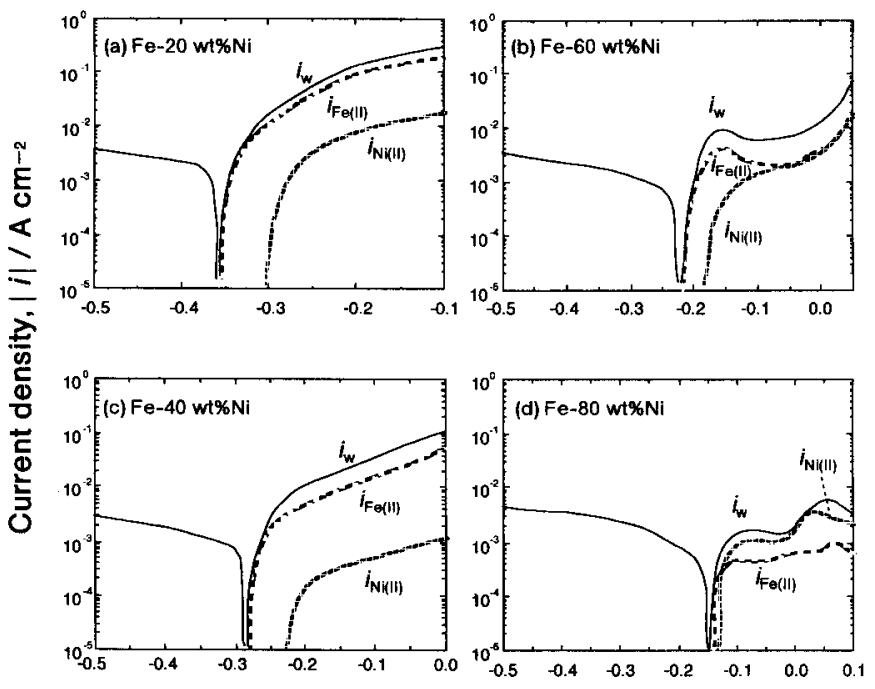

Potential, E / V vs.SSE

Fig. 3 Polarization curves of Fe- $x$ wt $\% \mathrm{Ni}(x=20,40,60$, 80 ) alloy and dissolution currents of $\mathrm{Fe}(\mathrm{II})_{\mathrm{sol}}, \mathrm{Ni}(\mathrm{II})_{\mathrm{sol}}$ in sulfuric acid solution ( $\mathrm{pH} 1)$. could be explained by adsorption of the species in the dissolution process of $\mathrm{Ni}$.

In Fig. 5, the capacitive and inductive semicircles are observed on $Z(\omega)$ of $\mathrm{Fe}-40 \mathrm{wt} \% \mathrm{Ni}$ alloy at $-0.25 \mathrm{~V}$. The two capacitive semicircles and one inductive semicircle appear on $Z(\omega)$ above $-0.2 \mathrm{~V}$. This behavior is as the same as that of $\mathrm{Fe}-20 \mathrm{wt} \% \mathrm{Ni}$ alloy.

In Fig. $6, Z(\omega)$ of $\mathrm{Fe}-60 \mathrm{wt} \% \mathrm{Ni}$ shows the same behavior as those presented in Figs. 4 and 5 below $-0.2 \mathrm{~V}$. On the other hand,a negative resistance, which is locus moving toward a negative real axis with decreasing the frequency on the complex plane, is observed in the $Z(\omega)$ plots at $0.1 \mathrm{~V}$.

In Fig. 7, a negative resistance is observed on the $Z$ $(\omega)$ plots of $\mathrm{Fe}-80 \mathrm{wt} \% \mathrm{Ni}$ alloy above $-0.05 \mathrm{~V}$. Generally the negative resistance originates from passivation, ${ }^{12)}$ however the polarization curve of $\mathrm{Fe}$ $80 \mathrm{wt} \%$ Ni doesn't show passivation at the potentials where $Z(\omega)$ 's are measured as shown in Fig. 3 . At the
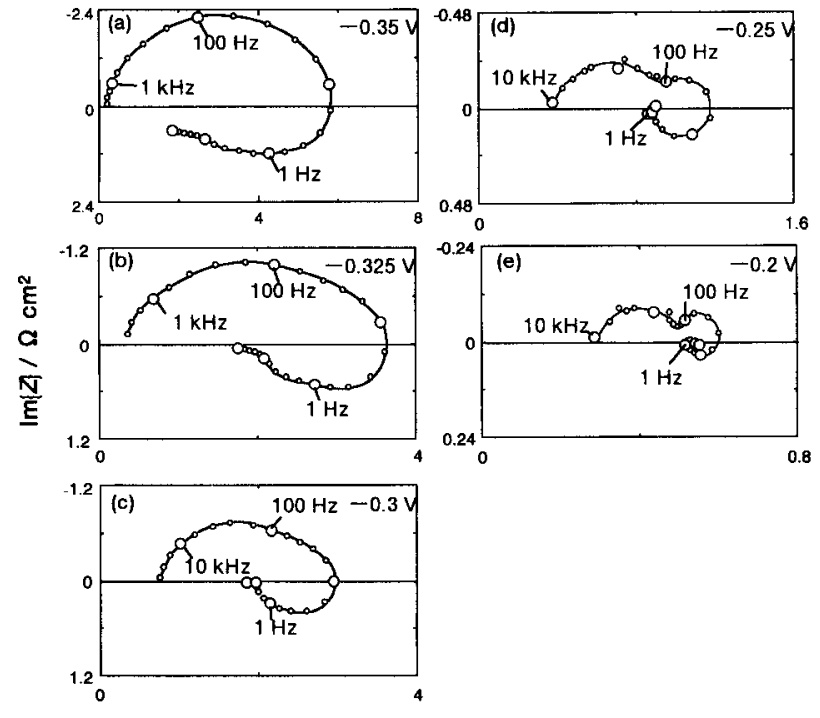

$\operatorname{Re}[Z] / \Omega \mathrm{cm}^{2}$

Fig. 4 Experimental results of electrochemical impedance of $\mathrm{Fe}-20 \mathrm{wt} \% \mathrm{Ni}$ in sulfuric acid solution $(\mathrm{pH} 1)$ at various electrode potentials.

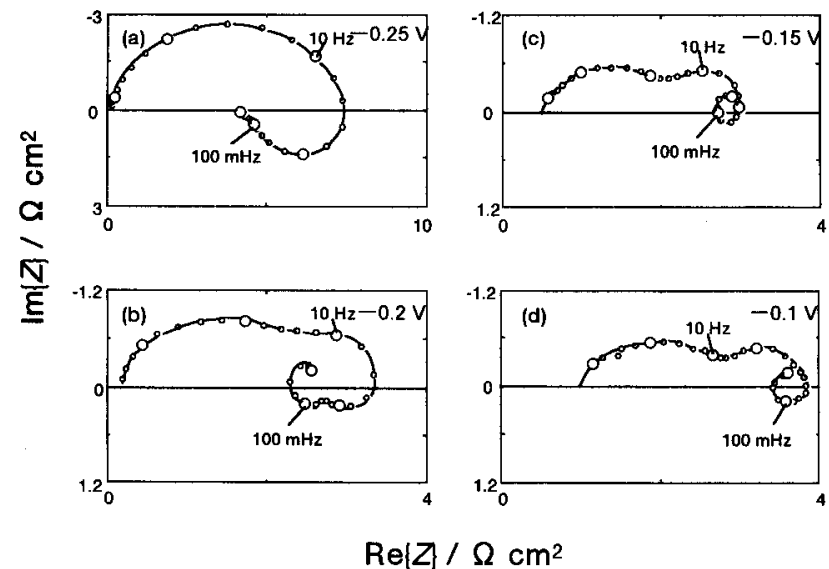

Fig. 5 Experimental results of electrochemical impedance of $\mathrm{Fe}-40 \mathrm{wt} \% \mathrm{Ni}$ in sulfuric acid solution $(\mathrm{pH} 1)$ at various electrode potentials. 


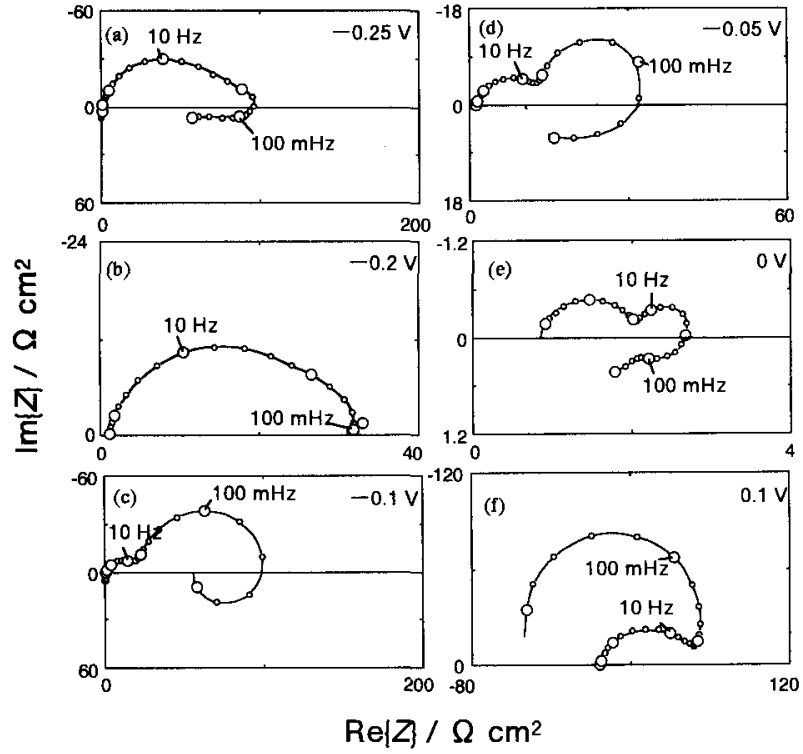

Fig. 6 Experimental results of electrochemical impedance of $\mathrm{Fe}-60 \mathrm{wt} \% \mathrm{Ni}$ in sulfuric acid solution $(\mathrm{pH} \mathrm{1}$ ) at various electrode potentials.

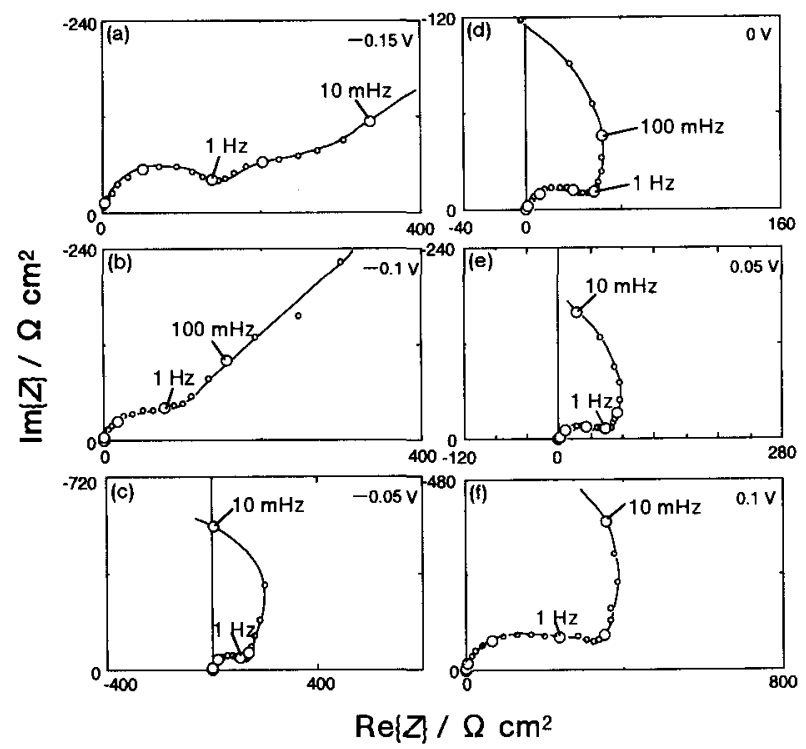

Fig. 7 Experimental results of electrochemical impedance of $\mathrm{Fe}-80 \mathrm{wt} \% \mathrm{Ni}$ in sulfuric acid solution $(\mathrm{pH} \mathrm{1)}$ at various electrode potentials.

conditions in which the negative resistance appears, the dissolution rate of $\mathrm{Ni}(\mathrm{II})$ is sufficient large comparing with that of $\mathrm{Fe}$ (II) in Fig. 3. This result means that the dissolution process of $\mathrm{Ni}$ is related with the negative resistance.

\section{Discussion}

\section{1 Dissolution model of $\mathrm{Fe}-\mathrm{Ni}$ alloy and deriva- tion of electrochemical impedance}

The following consecutive reactions ${ }^{13)}$ are used to represent the $\mathrm{Fe}$ (II) dissolution process from $\mathrm{Fe}-\mathrm{Ni}$ alloy in the present paper.

$\mathrm{Fe} \rightarrow \mathrm{Fe}(\mathrm{I})_{\mathrm{ad}}+\mathrm{e}^{-}$(reaction rate constant: $\left.K_{1}\right)(3)$

$\mathrm{Fe}(\mathrm{I})_{\mathrm{ad}} \rightarrow \mathrm{Fe}(\mathrm{II})+\mathrm{e}^{-}$(reaction rate constant: $\left.K_{2}\right)(4)$ where $K_{\mathrm{i}}$ is a reaction rate constant, and has the following relation with the electrode potential $E$. The subscript "ad" means adsorbed intermediate.

$$
K_{\mathrm{i}}=k_{\mathrm{i}} \exp \left(b_{\mathrm{i}} E\right)
$$

where $k_{\mathrm{i}}$ is a constant, and $b_{\mathrm{i}}$ is a Tafel constant. According to the previous paper, ${ }^{14)}$ the active dissolution of $\mathrm{Ni}$ proceeds by the following reactions.

$$
\begin{aligned}
& \mathrm{Ni} \rightleftarrows \mathrm{Ni}(\mathrm{I})_{\mathrm{ad}}+\mathrm{e}^{-} \\
& \text {(oxidation rate constant: } K_{3} \text {, reduc- } \\
& \text { tion rate constant: } K_{-3} \text { ) }
\end{aligned}
$$

$\mathrm{Ni}(\mathrm{I})_{\mathrm{ad}} \rightarrow \mathrm{Ni}(\mathrm{II})+\mathrm{e}^{-}$(reaction rate constant: $\left.K_{4}\right)(7)$

On the basis of the above reactions, the simulation is performed for the electrochemical behavior of $\mathrm{Fe}-\mathrm{Ni}$ alloys obtained in the present paper with the following assumptions.

1) Adsorption and charge transfer happen on the two-dimensional electrode surface.

2) The interaction among adsorbed species is neglected.

3) The reaction rate changes exponentially with the electrode potential (equation(5)).

The mass balance of $\mathrm{Fe}(\mathrm{I})_{\mathrm{ad}}$ and $\mathrm{Ni}(\mathrm{I})_{\mathrm{ad}}$ are written as below according to the equations (3), (4), (6) and (7).

$$
\begin{gathered}
\beta\left(\mathrm{d} \theta_{\mathrm{Fe}} / \mathrm{d} t\right)=K_{1}\left(1-\theta_{\mathrm{Fe}}-\theta_{\mathrm{Ni}}\right)-K_{2} \theta_{\mathrm{Fe}} \\
\beta\left(\mathrm{d} \theta_{\mathrm{Ni}} / \mathrm{d} t\right)=K_{3}\left(1-\theta_{\mathrm{Fe}}-\theta_{\mathrm{Ni}}\right)-\left(K_{4}+K_{-3}\right) \theta_{\mathrm{Ni}}
\end{gathered}
$$

where $\theta_{\mathrm{Fe}}$ and $\theta_{\mathrm{N} 1}$ are the fractional coverages of $\mathrm{Fe}(\mathrm{I})_{\mathrm{ad}}$ and $\mathrm{Ni}(\mathrm{I})_{\mathrm{ad}}$, respectively, and $\beta$ is surface concentration $\left.(\mathrm{mol} \mathrm{cm})^{-2}\right)$ as monolayer on the electrode when $\theta=1$. At the steady-state:

$$
\begin{aligned}
& \mathrm{d} \theta_{\mathrm{Fe}} / \mathrm{d} t=0, \\
& \mathrm{~d} \theta_{\mathrm{Ni}} / \mathrm{d} t=0 .
\end{aligned}
$$

From the equations (8) and (9), the steady-state coverages of $\mathrm{Fe}(\mathrm{I})_{\mathrm{ad}}, \Theta_{\mathrm{Fe}}$, and $\mathrm{Ni}(\mathrm{I})_{\mathrm{ad}}, \Theta_{\mathrm{Ni}}$, are:

$\Theta_{\mathrm{Fe}}=\left(K_{1} K_{4}+K_{1} K_{-3}\right) /\left(K_{1} K_{4}+K_{1} K_{-3}+K_{2} K_{4}+K_{2} K_{3}+\right.$ $K_{2} K_{-3}$ )

$\Theta_{\mathrm{Ni}}=K_{2} K_{3} /\left(K_{1} K_{4}+K_{1} K_{-3}+K_{2} K_{4}+K_{2} K_{3}+K_{2} K_{-3}\right)(13)$

The equations (8) and (9) are transformed into the frequency domain and by Taylor expansion as follows.

$$
\begin{gathered}
\left(j \omega \beta+K_{1}+K_{2}\right) \Delta \theta_{\mathrm{Fe}} / \Delta E+K_{1} \Delta \theta_{\mathrm{Ni}} / \Delta E= \\
b_{1} K_{1}\left(1-\Theta_{\mathrm{Fe}}-\Theta_{\mathrm{Ni}}\right)-b_{2} K_{2} \Theta_{\mathrm{Fe}} \\
K_{3} \Delta \theta_{\mathrm{Fe}} / \Delta E+(14) \\
b_{3} K_{3}\left(1-\Theta_{\mathrm{Fe}}-\Theta_{3}\right)-\left(b_{4} K_{4}+b_{-3} K_{-3}\right) \Theta_{\mathrm{Ni}}(15)
\end{gathered}
$$

From the charge balance in reactions (3), (4), (6) and (7), the working electrode current $i_{\mathrm{w}}$ and the dissolution currents of $\mathrm{Fe}(\mathrm{II}), i_{\mathrm{Fe}(\mathrm{II})}$, and $\mathrm{Ni}(\mathrm{II}), i_{\mathrm{Ni}(\mathrm{II})}$, are written as follows.

$$
\begin{aligned}
i_{\mathrm{w}}=F\left\{\left(K_{1}+K_{3}\right)\left(1-\theta_{\mathrm{Fe}}-\theta_{\mathrm{Ni}}\right)+K_{2} \theta_{\mathrm{Fe}}+\left(K_{4}-K_{-3}\right) \theta_{\mathrm{Ni}}\right. \\
i_{\mathrm{Fe}(\mathrm{II})}=2 F K_{2} \theta_{\mathrm{re}} \\
i_{\mathrm{Ni}(\mathrm{II})}=2 F K_{4} \theta_{\mathrm{Ni}}
\end{aligned}
$$

The equation (16) is transformed into:

$$
\begin{array}{r}
\Delta i_{\mathrm{w}} / \Delta E=F\left[\left\{\left(b_{1} K_{1}+b_{3} K_{3}\right)\left(1-\Theta_{\mathrm{Fe}}-\Theta_{\mathrm{Ni}}\right)+b_{2} K_{2} \Theta_{\mathrm{Fe}}\right.\right. \\
\left.+\left(b_{4} K_{4}-b_{-3} K_{-3}\right) \Theta_{\mathrm{Ni}}\right\}+\left(-K_{1}+K_{2}-K_{3}\right)\left(\Delta \theta_{\mathrm{Fe}} / \Delta E\right) \\
\left.\quad+\left(-K_{1}-K_{3}-K_{-3}+K_{4}\right)\left(\Delta \theta_{\mathrm{Ni}} / \Delta E\right)\right]
\end{array}
$$

The Faradaic impedance $Z_{\mathrm{F}}(\omega)$ is calculated by:

$$
Z_{\mathrm{F}}(\omega)=\Delta E / \Delta i_{\mathrm{W}}
$$

\section{2 Simulated results of $Z(\omega)$ of $\mathrm{Fe}-\mathrm{Ni}$ alloy}

The elcctrochemical impedance $Z(\omega)$ of liquid/ solid interface is composed of $Z_{\mathrm{F}}(\omega)$ and the capacitance of electric double layer $C_{\mathrm{d} 1}$. 


$$
1 / Z(\omega)=1 / Z_{\mathrm{F}}(\omega)+j \omega C_{\mathrm{c} 1}
$$

The $Z(\omega)$ 's of $\mathrm{Fe}-20 \mathrm{wt} \% \mathrm{Ni}$ alloy simulated according to the calculation method in the previous section are shown in Fig. 8. The one pair of capacitive and inductive semicircles is shown below $-0.3 \mathrm{~V}$. The inductive behavior is explained by the formation of the adsorbed intermediate $\mathrm{Fe}(\mathrm{I})_{\mathrm{ad}}$ in the reactions (3) and (4). Above $-0.25 \mathrm{~V}$, two capacitive semicircles and one inductive semicircle are simulated. The locus and its potential dependence of the simulated $Z(\omega)$ agree well with the results in Fig. 4. However, the frequency for each plot is not agreement with that in Fig. 4 perfectly. In this simulation, since five pairs of $b_{1}$ and $K_{1}$ were determined at the same time, the accuracies of the parameters were not high. The descrepancy between Figs. 4 and 8 originates from the parameters $K$ 's were obtained to one significant digit due to low accuracy. Though a capacitive semicircle is explained by the time constant of reaction resistance and $C_{\mathrm{d} 1}$ generally, the second capacitive semicircle, which appears on $Z(\omega)$ above $-0.25 \mathrm{~V}$, originates from the action of adsorbed intermediate $\mathrm{Ni}(\mathrm{I})_{\text {ad }}$.

The simulated $Z(\omega)$ 's of Fe-40 wt\% Ni alloy are shown in Fig. 9. The two capacitive and one inductive semicircles are simulated, and in agreement with the experimental results in Fig. 5. In experiment results in Fig. 5, however, the third capacitive semicircle is

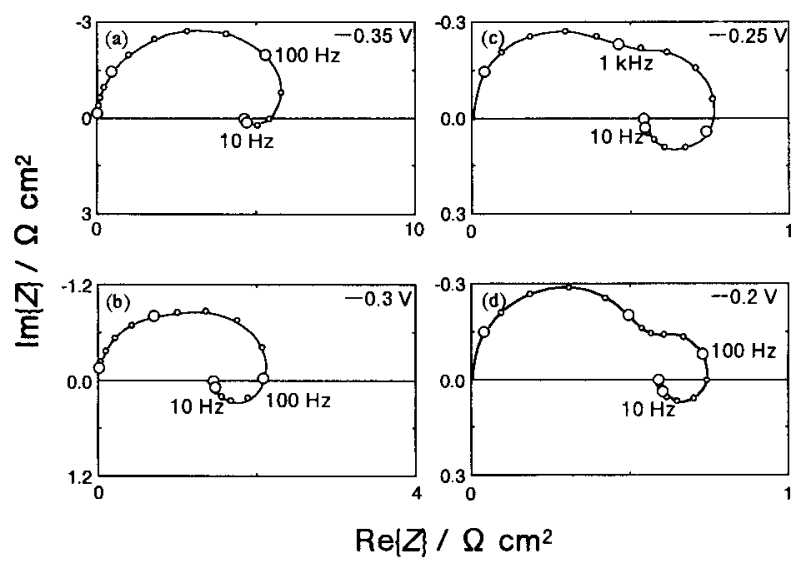

Fig. 8 Simulated results of electrochemical impedance of $\mathrm{Fe}-20 \mathrm{wt} \% \mathrm{Ni}$ in sulfuric acid solution $(\mathrm{pH} \mathrm{1)}$ at various electrode potentials. The parameters for the simulation are as follows:

$\beta=10^{-8} \mathrm{~mol} \mathrm{~cm} \mathrm{~cm}^{-2}, \quad b_{1}=38 \mathrm{~V}^{-1}, \quad b_{2}=7 \mathrm{~V}^{-1}, \quad b_{3}=13 \mathrm{~V}^{-1}$, $b_{-3}=-13 \mathrm{~V}^{-1}, b_{4}=18 \mathrm{~V}^{-1}$,

(a) $K_{1}=3 \times 10^{-8} \mathrm{~mol} \mathrm{~cm}{ }^{-2} \mathrm{~s}^{-1}, K_{2}=3 \times 10^{-6} \mathrm{~mol} \mathrm{~cm}{ }^{-2} \mathrm{~s}^{-1}$, $K_{3}=10^{-8} \mathrm{~mol} \mathrm{~cm} \mathrm{~cm}^{-2} \mathrm{~s}^{-1}, K_{-3}=10^{-5} \mathrm{~mol} \mathrm{~cm}^{-2} \mathrm{~s}^{-1}$,

$K_{4}=10^{-9} \mathrm{~mol} \mathrm{~cm}^{-2} \mathrm{~s}^{-1}$,

(b) $K_{1}=10^{-7} \mathrm{~mol} \mathrm{~cm}{ }^{-2} \mathrm{~s}^{-1}, \quad K_{2}=3 \times 10^{-6} \mathrm{~mol} \mathrm{~cm}^{-2} \mathrm{~s}^{-1}$, $K_{3}=10^{-7} \mathrm{~mol} \mathrm{~cm} \mathrm{~cm}^{-2} \mathrm{~s}^{-1}, K_{-3}=3 \times 10^{-5} \mathrm{~mol} \mathrm{~cm} \mathrm{~cm}^{-2} \mathrm{~s}^{-1}$,

$K_{4}=3 \times 10^{-8} \mathrm{~mol} \mathrm{~cm}^{-2} \mathrm{~s}^{-1}$,

(c) $K_{1}=3 \times 10^{-7} \mathrm{~mol} \mathrm{~cm}{ }^{-2} \mathrm{~s}^{-1}, K_{2}=3 \times 10^{-6} \mathrm{~mol} \mathrm{~cm}^{-2} \mathrm{~s}^{-1}$, $K_{3}=3 \times 10^{-7} \mathrm{~mol} \mathrm{~cm}{ }^{-2} \mathrm{~s}^{-1}, K_{-3}=3 \times 10^{-5} \mathrm{~mol} \mathrm{~cm} \mathrm{~cm}^{-2} \mathrm{~s}^{-1}$, $K_{4}=3 \times 10^{-7} \mathrm{~mol} \mathrm{~cm}^{-2} \mathrm{~s}^{-1}$,

(d) $K_{1}=3 \times 10^{-7} \mathrm{~mol} \mathrm{~cm} \mathrm{~cm}^{-2} \mathrm{~s}^{-1}, K_{2}=2 \times 10^{-6} \mathrm{~mol} \mathrm{~cm} \mathrm{~cm}^{-2} \mathrm{~s}^{-1}$, $K_{3}=3 \times 10^{-7} \mathrm{~mol} \mathrm{~cm}{ }^{-2} \mathrm{~s}^{-1}, K_{-3}=1 \times 10^{-5} \mathrm{~mol} \mathrm{~cm} \mathrm{~cm}^{-2} \mathrm{~s}^{-1}$, $K_{4}=3 \times 10^{-7} \mathrm{~mol} \mathrm{~cm}^{-2} \mathrm{~s}^{-1}$.

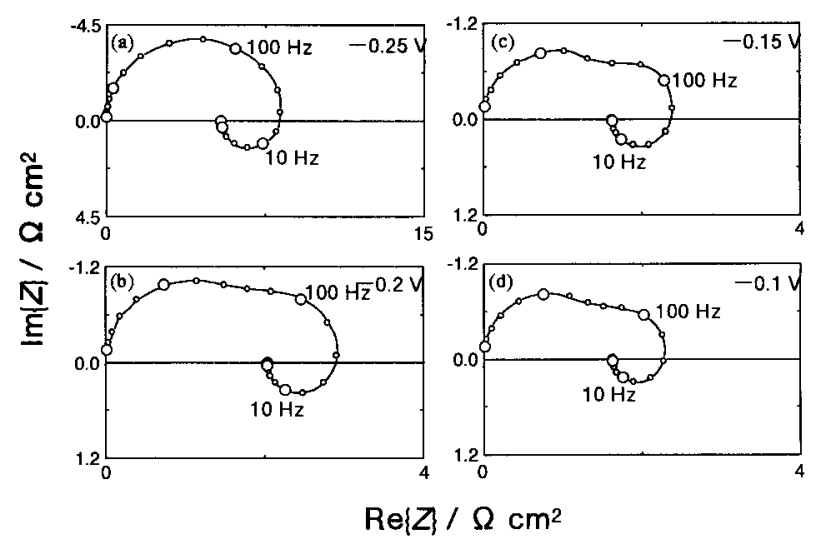

Fig. 9 Simulated results of electrochemical impedance of $\mathrm{Fe}-40 \mathrm{wt} \% \mathrm{Ni}$ in sulfuric acid solution $(\mathrm{pH} \mathrm{1)}$ at various electrode potentials. The parameters for the simulation are as follows:

$\beta=10^{-8} \mathrm{~mol} \mathrm{~cm} \mathrm{~cm}^{-2}, \quad b_{1}=38 \mathrm{~V}^{-1}, \quad b_{2}=7 \mathrm{~V}^{-1}, \quad b_{3}=13 \mathrm{~V}^{-1}$, $b_{-3}=-13 \mathrm{~V}^{-1}, b_{4}=18 \mathrm{~V}^{-1}$,

(a) $K_{1}=3 \times 10^{-8} \mathrm{~mol} \mathrm{~cm}^{-2} \mathrm{~s}^{-1}, K_{2}=3 \times 10^{-7} \mathrm{~mol} \mathrm{~cm} \mathrm{~cm}^{-2} \mathrm{~s}^{-1}$, $K_{3}=10^{-8} \mathrm{~mol} \mathrm{~cm} \mathrm{~cm}^{-2} \mathrm{~s}^{-1}, K_{-3}=10^{-5} \mathrm{~mol} \mathrm{~cm} \mathrm{~cm}^{-2} \mathrm{~s}^{-1}$,

$K_{4}=1 \times 10^{-8} \mathrm{~mol} \mathrm{~cm}^{-2} \mathrm{~s}^{-1}$,

(b) $K_{1}=8 \times 10^{-8} \mathrm{~mol} \mathrm{~cm} \mathrm{~cm}^{-2} \mathrm{~s}^{-1}, K_{2}=8 \times 10^{-7} \mathrm{~mol} \mathrm{~cm} \mathrm{~cm}^{-2} \mathrm{~s}^{-1}$, $K_{3}=8 \times 10^{-8} \mathrm{~mol} \mathrm{~cm}{ }^{-2} \mathrm{~s}^{-1}, K_{-3}=10^{-5} \mathrm{~mol} \mathrm{~cm} \mathrm{~cm}^{-2} \mathrm{~s}^{-1}$,

$K_{4}=8 \times 10^{-8} \mathrm{~mol} \mathrm{~cm}^{-2} \mathrm{~s}^{-1}$,

(c) $K_{1}=10^{-7} \mathrm{~mol} \mathrm{~cm}^{-2} \mathrm{~s}^{-1}, K_{2}=10^{-6} \mathrm{~mol} \mathrm{~cm} \mathrm{~cm}^{-2} \mathrm{~s}^{-1}$, $K_{3}=10^{-7} \mathrm{~mol} \mathrm{~cm} \mathrm{~cm}^{-2} \mathrm{~s}^{-1}, K_{-3}=2 \times 10^{-5} \mathrm{~mol} \mathrm{~cm} \mathrm{~cm}^{-2} \mathrm{~s}^{-1}$, $K_{4}=10^{-7} \mathrm{~mol} \mathrm{~cm} \mathrm{~cm}^{-2} \mathrm{~s}^{-1}$,

(d) $K_{1}=10^{-7} \mathrm{~mol} \mathrm{~cm} \mathrm{~cm}^{-2} \mathrm{~s}^{-1}, K_{2}=10^{-6} \mathrm{~mol} \mathrm{~cm} \mathrm{~cm}^{-2} \mathrm{~s}^{-1}$, $K_{3}=10^{-7} \mathrm{~mol} \mathrm{~cm} \mathrm{~cm}^{-2} \mathrm{~s}^{-1}, K_{-3}=10^{-5} \mathrm{~mol} \mathrm{~cm} \mathrm{~cm}^{-2} \mathrm{~s}^{-1}$, $K_{4}=10^{-7} \mathrm{~mol} \mathrm{~cm} \mathrm{~cm}^{-2} \mathrm{~s}^{-1}$.

observed at low frequency range around $10 \mathrm{mHz}$. Though the simulation assuming the third absorbed intermediate, which has very low formation rate, is necessary to represent the third capacitive semicircle, it is neglected in the present analysis for a simplification.

The simulated $Z(\omega)$ 's of $\mathrm{Fe}-60 \mathrm{wt} \% \mathrm{Ni}$ alloy are shown in Fig. 10. Below $0.0 \mathrm{~V}$, the $Z(\omega)$ shows the similar behavior to those of $\mathrm{Fe}-20 \mathrm{wt} \% \mathrm{Ni}$ and $\mathrm{Fe}-40$ wt $\% \mathrm{Ni}$ alloys. Furthermore, negative resistance observed in $0.1 \mathrm{~V}$ is reproduced. Above-mentioned simulation results agree with experiment results shown with Fig. 6 . The simulated $Z$ ( $\omega)$ 's of Fe-80 wt $\% \mathrm{Ni}$ alloy are shown in Fig. 11. The negative resistance is reproduced above $0.05 \mathrm{~V}$, and agrees with experiment results in Fig. 7.

When the potential becomes nobler in all cases of $\mathrm{Ni}$ contents, a values of $K_{1}$ and $K_{3}$ become larger, as indicated by equation (5) in small anodic polarizations. In large anodic polarizations, the values $K_{1}$ and $K_{3}$ of deviate from the relation of equation (5). This deviation originates from the change of surface activity of alloy element due to rapid dissolution in large anodic polarizations. Though the surface activities were not determined in this paper, the surface concentration of alloy element is significant parameter to discuss the active dissolution of alloy. For example, the value of $K_{1}$ at $-0.2 \mathrm{~V}$ is getting smaller with 


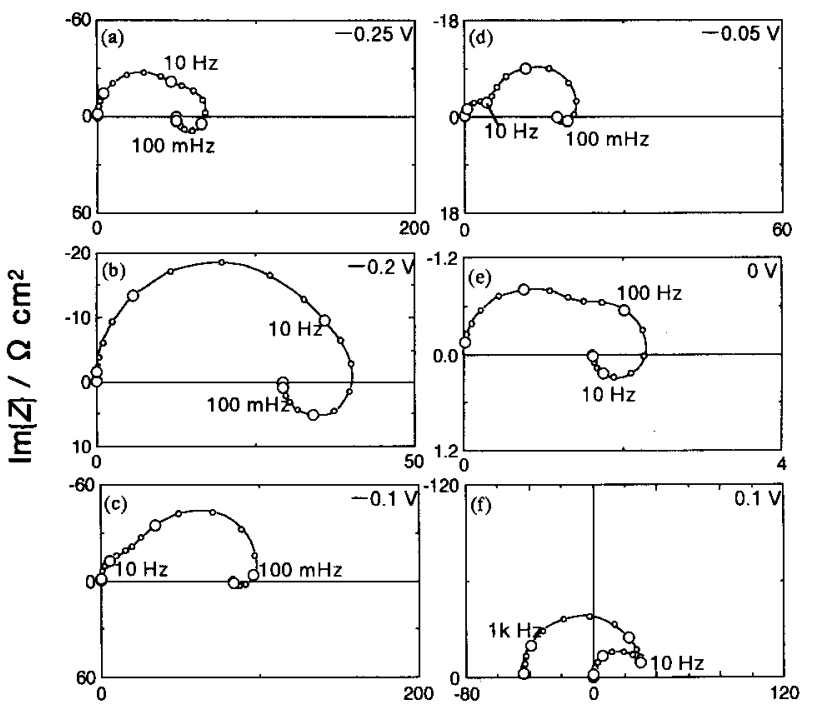

$\operatorname{Re}[Z] / \Omega \mathrm{cm}^{2}$

Fig. 10 Simulated results of electrochemical impedance of $\mathrm{Fe}-60 \mathrm{wt} \% \mathrm{Ni}$ in sulfuric acid solution $(\mathrm{pH} 1)$ at various electrode potentials. The parameters for the simulation are as follows:

$\beta=10^{-8} \mathrm{~mol} \mathrm{~cm}{ }^{-2}, \quad b_{1}=38 \mathrm{~V}^{-1}, \quad b_{2}=7 \mathrm{~V}^{-1}, \quad b_{3}=13 \mathrm{~V}^{-1}$, $b_{-3}=-13 \mathrm{~V}^{-1}, b_{4}=18 \mathrm{~V}^{-1}$

(a) $K_{1}=3 \times 10^{-9} \mathrm{~mol} \mathrm{~cm}^{-2} \mathrm{~s}^{-1}, K_{2}=3 \times 10^{-8} \mathrm{~mol} \mathrm{~cm} \mathrm{~cm}^{-2} \mathrm{~s}^{-1}$, $K_{3}=3 \times 10^{-9} \mathrm{~mol} \mathrm{~cm} \mathrm{~cm}^{-2} \mathrm{~s}^{-1}, K_{-3}=3 \times 10^{-7} \mathrm{~mol} \mathrm{~cm} \mathrm{~cm}^{-2} \mathrm{~s}^{-1}$, $K_{4}=3 \times 10^{-8} \mathrm{~mol} \mathrm{~cm} \mathrm{~cm}^{-2} \mathrm{~s}^{-1}$,

(b) $K_{1}=3 \times 10^{-9} \mathrm{~mol} \mathrm{~cm}^{-2} \mathrm{~s}^{-1}, K_{2}=4 \times 10^{-8} \mathrm{~mol} \mathrm{~cm} \mathrm{~cm}^{-2} \mathrm{~s}^{-1}$, $K_{3}=3 \times 10^{-9} \mathrm{~mol} \mathrm{~cm}{ }^{-2} \mathrm{~s}^{-1}, K_{-3}=3 \times 10^{-7} \mathrm{~mol} \mathrm{~cm} \mathrm{~cm}^{-2} \mathrm{~s}^{-1}$, $K_{4}=5 \times 10^{-8} \mathrm{~mol} \mathrm{~cm} \mathrm{~cm}^{-2} \mathrm{~s}^{-1}$,

(c) $K_{1}=10^{-9} \mathrm{~mol} \mathrm{~cm}^{-2} \mathrm{~s}^{-1}, K_{2}=5 \times 10^{-8} \mathrm{~mol} \mathrm{~cm} \mathrm{~cm}^{-2} \mathrm{~s}^{-1}$,

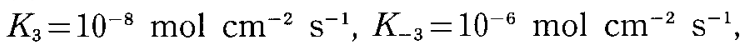

$K_{4}=7 \times 10^{-8} \mathrm{~mol} \mathrm{~cm}{ }^{-2} \mathrm{~s}^{-1}$,

(d) $K_{1}=10^{-7} \mathrm{~mol} \mathrm{~cm}{ }^{-2} \mathrm{~s}^{-1}, K_{2}=10^{-6} \mathrm{~mol} \mathrm{~cm} \mathrm{~cm}^{-2} \mathrm{~s}^{-1}$,

$K_{3}=10^{-7} \mathrm{~mol} \mathrm{~cm}{ }^{-2} \mathrm{~s}^{-1}, K_{-3}=10^{-6} \mathrm{~mol} \mathrm{~cm}{ }^{-2} \mathrm{~s}^{-1}$,

$K_{4}=10^{-7} \mathrm{~mol} \mathrm{~cm}{ }^{-2} \mathrm{~s}^{-1}$,

(e) $K_{1}=3 \times 10^{-8} \mathrm{~mol} \mathrm{~cm} \mathrm{~cm}^{-2}, K_{2}=10^{-9} \mathrm{~mol} \mathrm{~cm} \mathrm{~cm}^{-2} \mathrm{~s}^{-1}$, $K_{3}=3 \times 10^{-7} \mathrm{~mol} \mathrm{~cm}{ }^{-2} \mathrm{~s}^{-1}, K_{-3}=3 \times 10^{-5} \mathrm{~mol} \mathrm{~cm}^{-2} \mathrm{~s}^{-1}$, $K_{4}=3 \times 10^{-3} \mathrm{~mol} \mathrm{~cm}{ }^{-2} \mathrm{~s}^{-1}$.

increasing the Ni component. Because the value of $K_{1}$ contains surface activity of Fe, the decrease should be caused by $\mathrm{Fe}$ component in the alloy. The degree of the decrease is more remarkable than a change of the Fe component. The above-mentioned result indicates that the formation rate of the adsorbed intermediate $\mathrm{Fe}(\mathrm{I})_{\text {ad }}$ (reaction (3)) and the dissolution rate from $\mathrm{Fe}(\mathrm{I})_{\mathrm{ad}}$ are controlled by the addition of $\mathrm{Ni}$ into $\mathrm{Fe}$.

4. 3 Simulated results of polarization curves of $\mathrm{Fe}-\mathrm{Ni}$ alloy and the fractional coverages of $\mathrm{Fe}(\mathrm{I})_{\mathrm{ad}}$ and $\mathrm{Ni}(\mathrm{I})_{\mathrm{ad}}$

Figure 12 shows the simulated results of polarization curves of $\mathrm{Fe}-\mathrm{Ni}$ alloy and their dissolution currents $i_{\mathrm{Fe}(\mathrm{II})}$ and $i_{\mathrm{Ni}(\mathrm{II})}$ calculated according to equations (12), (13), (16), (17) and (18). These simulated results agree with the measurement results presented in Fig. 3 qualitatively. The steady-state coverages of $\mathrm{Fe}(\mathrm{I})_{\mathrm{ad}}$, $\Theta_{\mathrm{Fe}}$, and $\mathrm{Ni}(\mathrm{I})_{\mathrm{ad}}, \Theta_{\mathrm{Ni}}$ calculated by equations (12) and (13) are shown in Fig. 13. The preferential dissolution

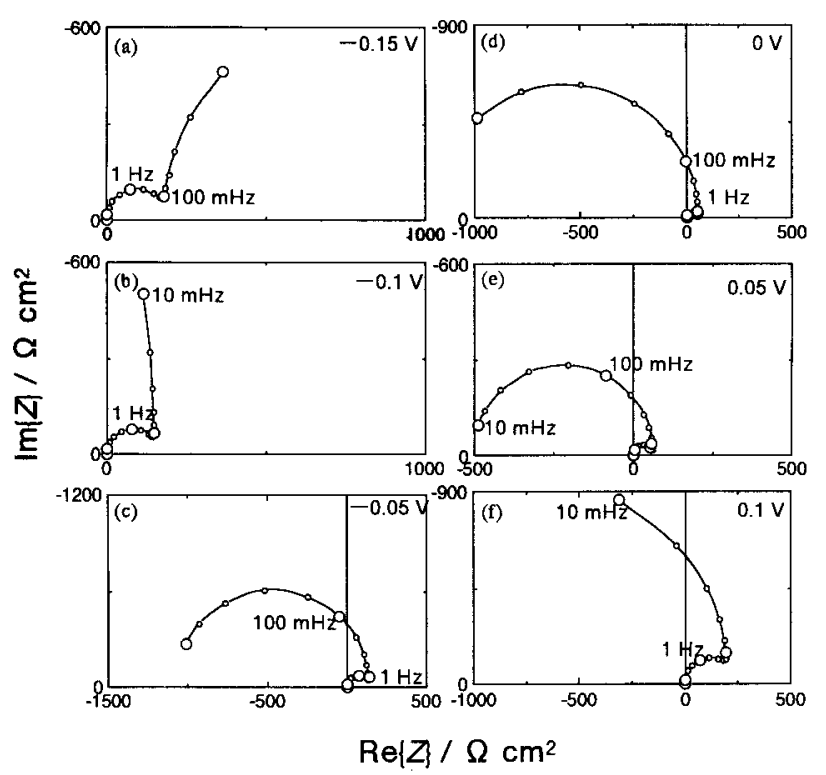

Fig. 11 Simulated results of electrochemical impedance of $\mathrm{Fe}-80 \mathrm{wt} \% \mathrm{Ni}$ in sulfuric acid solution ( $\mathrm{pH} 1$ ) at various electrode potentials. The parameters for the simulation are as follows:

$\beta=10^{-8} \mathrm{~mol} \mathrm{~cm} \mathrm{~cm}^{-2}, \quad b_{1}=38 \mathrm{~V}^{-1}, \quad b_{2}=7 \mathrm{~V}^{-1}, \quad b_{3}=13 \mathrm{~V}^{-1}$, $b_{-3}=-13 \mathrm{~V}^{-1}, b_{4}=18 \mathrm{~V}^{-1}$

(a) $K_{1}=2 \times 10^{-8} \mathrm{~mol} \mathrm{~cm} \mathrm{~cm}^{-2} \mathrm{~s}^{-1}, \quad K_{2}=2 \times 10^{-10} \mathrm{~mol} \mathrm{~cm} \mathrm{~cm}^{-2}$ $\mathrm{s}^{-1}, \quad K_{3}=2 \times 10^{-7} \mathrm{~mol} \mathrm{~cm}^{-2} \mathrm{~s}^{-1}, \quad K_{-3}=2 \times 10^{-5} \mathrm{~mol} \mathrm{~cm}^{-2}$ $\mathrm{s}^{-1}, K_{4}=10^{-5} \mathrm{~mol} \mathrm{~cm} \mathrm{~cm}^{-2} \mathrm{~s}^{-1}$,

(b) $K_{1}=2 \times 10^{-8} \mathrm{~mol} \mathrm{~cm}^{-2} \mathrm{~s}^{-1}, \quad K_{2}=2 \times 10^{-10} \mathrm{~mol} \mathrm{~cm} \mathrm{~cm}^{-2}$ $\mathrm{s}^{-1}, \quad K_{3}=2 \times 10^{-7} \mathrm{~mol} \mathrm{~cm} \mathrm{~cm}^{-2} \mathrm{~s}^{-1}, \quad K_{-3}=2 \times 10^{-5} \mathrm{~mol} \mathrm{~cm} \mathrm{~cm}^{-2}$ $\mathrm{s}^{-1}, K_{4}=2 \times 10^{-5} \mathrm{~mol} \mathrm{~cm} \mathrm{~cm}^{-2} \mathrm{~s}^{-1}$,

(c) $K_{1}=2 \times 10^{-8} \mathrm{~mol} \mathrm{~cm} \mathrm{~cm}^{-2} \mathrm{~s}^{-1}, K_{2}=2 \times 10^{-10} \mathrm{~mol} \mathrm{~cm} \mathrm{~cm}^{-2}$ $\mathrm{s}^{-1}, \quad K_{3}=2 \times 10^{-7} \mathrm{~mol} \mathrm{~cm} \mathrm{~cm}^{-2} \mathrm{~s}^{-1}, \quad K_{-3}=2 \times 10^{-5} \mathrm{~mol} \mathrm{~cm}^{-2}$ $\mathrm{s}^{-1}, K_{4}=3 \times 10^{-5} \mathrm{~mol} \mathrm{~cm} \mathrm{~cm}^{-2} \mathrm{~s}^{-1}$,

(d) $K_{1}=3 \times 10^{-8} \mathrm{~mol} \mathrm{~cm}^{-2} \mathrm{~s}^{-1}, \quad K_{2}=3 \times 10^{-10} \mathrm{~mol} \mathrm{~cm} \mathrm{~cm}^{-2}$ $\mathrm{s}^{-1}, K_{3}=6 \times 10^{-7} \mathrm{~mol} \mathrm{~cm} \mathrm{~cm}^{-2} \mathrm{~s}^{-1}, \quad K_{-3}=3 \times 10^{-5} \mathrm{~mol} \mathrm{~cm}^{-2}$

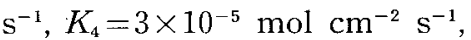

(e) $K_{1}=3 \times 10^{-8} \mathrm{~mol} \mathrm{~cm} \mathrm{~cm}^{-2} \mathrm{~s}^{-1}, \quad K_{2}=4 \times 10^{-10} \mathrm{~mol} \mathrm{~cm} \mathrm{~cm}^{-2}$ $\mathrm{s}^{-1}, \quad K_{3}=1 \times 10^{-7} \mathrm{~mol} \mathrm{~cm}{ }^{-2} \mathrm{~s}^{-1}, \quad K_{-3}=3 \times 10^{-5} \mathrm{~mol} \mathrm{~cm}^{-2}$ $\mathrm{s}^{-1}, K_{4}=4 \times 10^{-5} \mathrm{~mol} \mathrm{~cm} \mathrm{~cm}^{-2} \mathrm{~s}^{-1}$,

(f) $K_{1}=4 \times 10^{-8} \mathrm{~mol} \mathrm{~cm}{ }^{-2} \mathrm{~s}^{-1}, K_{2}=2 \times 10^{-10} \mathrm{~mol} \mathrm{~cm} \mathrm{~cm}^{-2} \mathrm{~s}^{-1}$, $K_{3}=5 \times 10^{-7} \mathrm{~mol} \mathrm{~cm}{ }^{-2} \mathrm{~s}^{-1}, \quad K_{-3}=3 \times 10^{-5} \mathrm{~mol} \mathrm{~cm} \mathrm{~cm}^{-2} \mathrm{~s}^{-1}$, $K_{4}=4 \times 10^{-5} \mathrm{~mol} \mathrm{~cm} \mathrm{~cm}^{-2} \mathrm{~s}^{-1}$.

of $\mathrm{Fe}(\mathrm{II})$ is reproduced for the alloy of small $\mathrm{Ni}$ component in Fig. 12, and coverage of $\mathrm{Ni}(\mathrm{I})_{\mathrm{ad}}, \Theta_{\mathrm{Ni}}$ is very small at the low anodic potentials. The calculated results in Fig. 13, which show that the almost adsorbed species are $\mathrm{Fe}(\mathrm{I})_{\mathrm{ad}}$ at low anodic potential, confirm that the inductive behavior of $Z(\omega)$ originates from the formation of $\mathrm{Fe}(\mathrm{I})_{\mathrm{ad}}$. In the case of Fe-20, 40, 60 wt $\% \mathrm{Ni}$ alloy, the second capacitive semicircle is observed in Figs. 4-6. The potential at which the second capacitive semicircle appears corresponds to the potential at which the $\Theta_{\mathrm{Ni}}$ become large beyond $10^{-2}$, indicating that the second capacitive semicircle is caused by the formation of $\mathrm{Ni}(\mathrm{I})_{\mathrm{ad}}$. Moreover, $\Theta_{\mathrm{N} 1}$ decreases at noble potentials, and $\Theta_{\mathrm{Fe}}$ increases with the increase of $\mathrm{Ni}$ content. These results could influence on the passivation of $\mathrm{Fe}-\mathrm{Ni}$ 

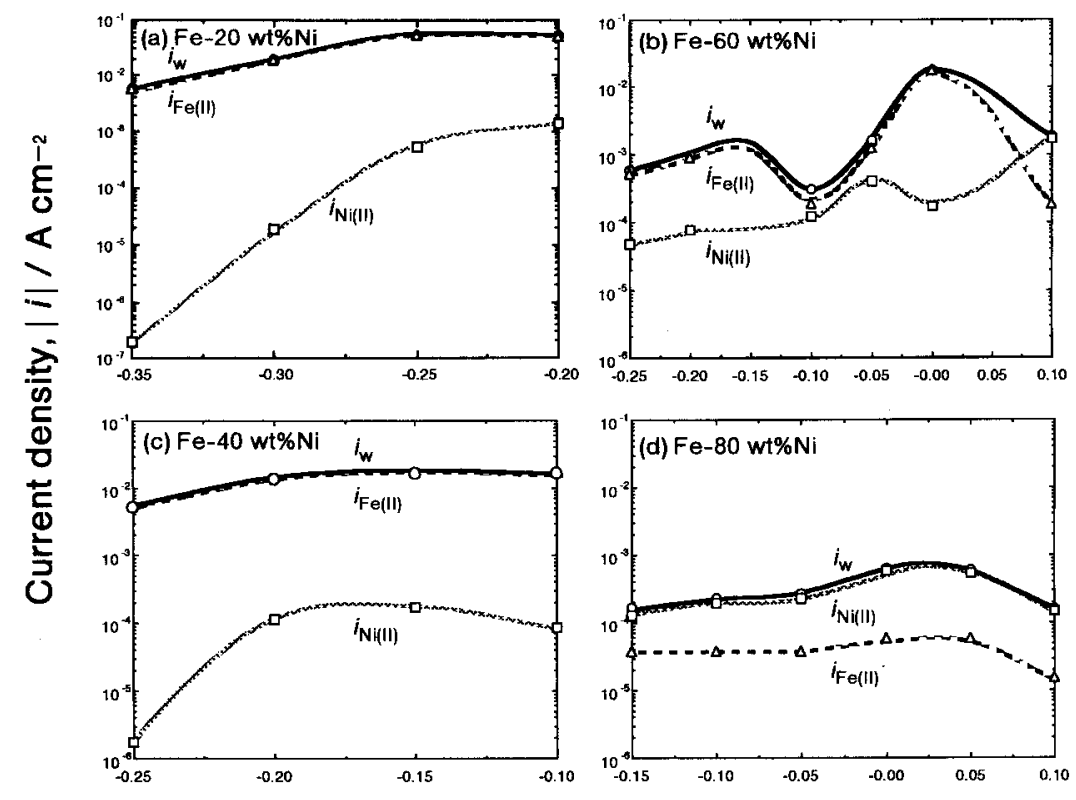

Potential, E / V vs.SSE

Fig. 12 Simulated results of polarization curves of $\mathrm{Fe}-x$ wt $\% \mathrm{Ni}(x=20,40,60,80)$ alloy and the dissolution currents of $\mathrm{Fe}(\mathrm{II}), \mathrm{Ni}(\mathrm{II})$ in sulfuric acid solution ( $\mathrm{pH}$ 1). The parameters for the simulation are referred to Figs. 8-11.
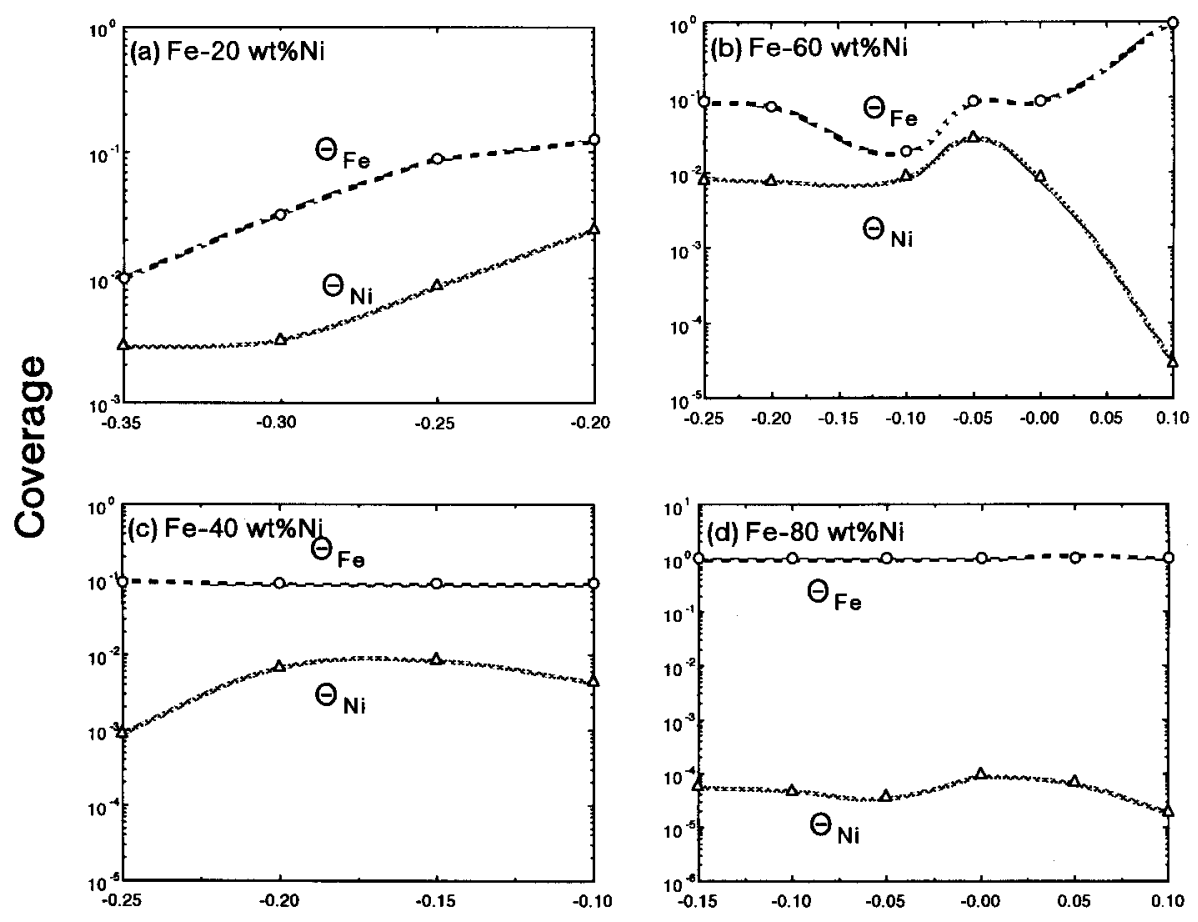

Potential, E / V vs.SSE

Fig. 13 Simulated results of steady-state coverages of the adsorbed species $\mathrm{Fe}(\mathrm{I})_{\mathrm{ad}}\left(\Theta_{\mathrm{Fe}}\right), \mathrm{Ni}(\mathrm{I})_{\mathrm{ad}}\left(\Theta_{\mathrm{Ni}}\right)$ of $\mathrm{Fe}-x \mathrm{wt} \% \mathrm{Ni}$ on alloy. The parameters for the simulation are referred to Figs. 8-11.

alloy.

\section{Conclusion}

First of all in the present paper, in situ detection of $\mathrm{Fe}(\mathrm{II})$ and $\mathrm{Ni}(\mathrm{II})$ dissolved from $\mathrm{Fe}-\mathrm{Ni}$ alloy electrode was done by separation type channel flow electrode, and the effect of $\mathrm{Ni}$ content on the alloy dissolution behavior was discussed. In the case of low Ni content, $\mathrm{Fe}-\mathrm{Ni}$ alloy showed a preferential dissolution of $\mathrm{Fe}$ (II) at anodic side near the immersion potential. The dissolution rate of $\mathrm{Fe}(\mathrm{II})$ was controlled significantly by $\mathrm{Ni}$ content.

In the analysis by EIS, the features of electrochemical impedance, i.e., two capacitive semicircles, 
an inductive semicircle and negative resistance, was discussed theoretically. The inductive semicircle was explained by the $\mathrm{Fe}(\mathrm{I})_{\mathrm{ad}}$ formation, and two capacitive semicircles were related to the time constants of the $\mathrm{Ni}(\mathrm{I})_{\mathrm{ad}}$ formation and of the reaction resistance and the double layer capacitance. The numerical simulation was performed for experimental results of $Z(\omega)$ and polarization curve. On the basis of kinetic parameters obtained by the simulation, the steady-state coverage $\Theta_{\mathrm{Fe}}$ and $\Theta_{\mathrm{N} 1}$ were calculated. The $\Theta_{\mathrm{N} i}$ is quite small comparing with $\Theta_{\mathrm{Fe}}$ at low anodic potential, indicating that $\mathrm{Ni}$ product does not inhibit the dissolution rate of $\mathrm{Fe}$ (II) by $\mathrm{Ni}$ addition but changes the free energy of $\mathrm{Fe}-\mathrm{Ni}$ alloy, as the reason why the immersion potential of $\mathrm{Fe}-\mathrm{Ni}$ alloy shifts toward positive with the increase of $\mathrm{Ni}$ content. The negative resistance in $Z$ appears when $\Theta_{\mathrm{Ni}}$ became larger than $\Theta_{\mathrm{Fe}}$.

\section{Acknowledgment}

The authors would like to appriciate the financial support by Grant in Aid (No. 10750533) from the Ministry of Education, Science, Sports and Culture, Japan.

\section{References}

1) H. Nagasaki, D. Someno, and T. Tin, J. Japan Inst.
Metals, 30, 714 (1966).

2) Y. Okuyama and S. Haruyama, J. Japan Inst. Metals, 37, 969 (1973).

3) S. Morioka and K. Sakiyama, J. Japan Inst. Metals, 19, 31 (1955).

4) P. Ponthiaux, F. Wenger, and J. Galland, J. Electrochem. Soc., 142, 2204 (1995).

5) Y. Okuyama, Denki Kagaku (presently Electrochemistry), 49, 149 (1981); 50, 320 (1982) (in Japanese).

6) M. Keddam, O. R. Mattos, and H. Takenouti, Electrochim.Acta, 31, 9 (1986).

7) I. Annergren, M. Keddam, H. Takenouti, and D. Thierry, Electrochim. Acta, 41, 1121 (1996).

8) T. Tsuru, Mater.Sci.Eng., A146, 1 (1991).

9) M. Saeki, A. Nisikata, and T. Tsuru, Denki Kagaku (presently Electrochemistry), 64, 891 (1996) (in Japanese).

10) I. Epelboin and M. Keddam, J. Electrochem. Soc., 117, 1052 (1970).

11) M. Itagaki and K. Watanabe, Denki Kagaku (presently Electrochemistry), 654, 9 (1977) (in Japanese).

12) I. Epelboin, C. Gabrielli, M. Keddam, and H. Takenouti, Comprehensive Treatise on Electrochemistry, 4, Plenum Press, N. Y., pp.151-192 (1981).

13) J. O'M. Bockris, D. Drazig, and A. Despic, Electrochim. Acta, 4, 325 (1961).

14) M. Itagaki, H. Nakazawa, K. Watanabe, and K. Noda, Corros. Sci., 39, 901 (1997). 